in vivo $35: 799-803(2021)$

doi:10.21873/invivo.12320

\title{
Significant Association of Chitinase 3-like 1 Genotypes to Asthma Risk in Taiwan
}

\author{
GUAN-LIANG CHEN ${ }^{1,2,3^{*}}$, SHOU-CHENG WANG ${ }^{2,3 *}$, TE-CHUN SHEN ${ }^{1,4,5}$, WEN-SHIN CHANG ${ }^{1,4}$, \\ CHINGJU LIN ${ }^{6}$, TE-CHUN HSIA ${ }^{4,5}$, DA-TIAN BAU ${ }^{1,4,7}$ and CHIA-WEN TSAI ${ }^{1,4}$ \\ ${ }^{1}$ Graduate Institute of Biomedical Sciences, China Medical University, Taichung, Taiwan, R.O.C.; \\ ${ }^{2}$ Division of Chest Medicine, Taichung Armed Forces General Hospital, Taichung, Taiwan, R.O.C.; \\ ${ }^{3}$ National Defense Medical Center, Taipei, Taiwan, R.O.C.; \\ ${ }^{4}$ Terry Fox Cancer Research Laboratory, Department of Medical Research, \\ China Medical University Hospital, Taichung, Taiwan, R.O.C.; \\ ${ }^{5}$ Division of Pulmonary and Critical Care Medicine, Department of Internal Medicine, \\ China Medical University Hospital, Taichung, Taiwan, R.O.C.; \\ ${ }^{6}$ Department of Physiology, School of Medicine, China Medical University, Taichung, Taiwan, R.O.C.; \\ ${ }^{7}$ Department of Bioinformatics and Medical Engineering, Asia University, Taichung, Taiwan, R.O.C.
}

\begin{abstract}
Background/Aim: Chitinase 3-like 1 (CHI3L1) is overexpressed in asthma, and negatively associated with forced expiratory volume in the first second. This study aimed at evaluating whether CHI3L1 genotypes affect asthma risk. Materials and Methods: The blood samples of 198 asthma patients and 453 control subjects were collected, and the genotypic patterns of CHI3L1 -131C/G (rs4950928) and -247G/A (rs1262491437) were examined. Results: The percentages of $C G$ and $G G$ at CHI3L $-131 C / G$ were $32.8 \%$ and $7.6 \%$ among the asthma cases, respectively, significantly higher than the $23.8 \%$ and $3.1 \%$ among the non-asthmatic healthy subjects ( $p$ for trend=0.0009). The allelic frequency distribution analysis showed that the G allele at CHI3L1 $131 C / G$ conferred a significantly higher asthma risk than the wild-type $C$ allele $(p<0.0001)$. The genotypic and allelic frequency analyses for CHI3L1 -247G/A did not show any significant difference. Conclusion: The G allele at CHI3L1 $-131 C / G$ serves as a biomarker in determining personal susceptibility to asthma in Taiwan.
\end{abstract}

This article is freely accessible online.

*These Authors contributed equally to this work.

Correspondence to: Da-Tian Bau and Chia-Wen Tsai, Terry Fox Cancer Research Laboratory, Department of Medical Research, China Medical University Hospital, 2 Yuh-Der Road, Taichung, 404 Taiwan, R.O.C. Tel: +886 422053366 (Ext. 5805), e-mail: datian@mail.cmuh.org.tw; artbau2@gmail.com

Key Words: Asthma, CHI3L1, genotype, polymorphism, Taiwan.
Asthma has a complex etiology, including chronic airway inflammation, bronchial hyper-responsiveness, and various degrees of airway obstruction (1). The most recent study has indicated that the global incidence of asthma has been 43.12 million new cases/year $(0.56 \%)$, while global prevalence and mortality accounted for 272.68 million cases (3.57\%) and 0.49 million deaths $(0.006 \%)$, respectively, in 2017 (2). The number is suggested to be increased to 400 million by 2025 and is a threat to our health (3). Although the exact etiology of asthma is still unrevealed, it is believed to be caused by specific interaction between genomic and environmental factors $(4,5)$.

The Chitinase 3-like 1 (CHI3Ll) gene is located on chromosome 1q32.1 (6) and encodes YKL-40 (7). As early as 2008, a genome-wide association study (GWAS) has identified $C H I 3 L 1$ as an asthma susceptibility gene with the evidence that its genotype may associate with airway hyper-responsiveness and decline in lung function in a Caucasian population (8). YKL-40 has been found to be pro-inflammatory and is released by activated human macrophage (9), vascular smooth muscle cells (10), and neutrophils (11). YKL-40 protein is involved in the Th2 cell mediated inflammatory pathway, tissue remodeling and fibrosis $(6,12)$ and may associate with the etiology of asthma. The incidence of asthma may vary in different countries and ethnicities. Since polymorphic sites in the promoter region may closely determine the expression levels of $C H I 3 L I$, we aimed to examine the association of the CHI3LI -131C/G (rs4950928) and $-247 \mathrm{G} / \mathrm{A}$ (rs1262491437) variants with adult asthma in Taiwan.

\section{Materials and Methods}

Collection of case and control groups. A total of 198 patients with asthma were recruited at the China Medical University Hospital 
in vivo $35: 799-803(2021)$

Table I. Distributions of age and gender among the 198 asthma patients and the 453 matched controls.

\begin{tabular}{|c|c|c|c|c|c|}
\hline \multirow[t]{2}{*}{ Characteristics } & \multicolumn{2}{|c|}{ Controls $(\mathrm{n}=453)$} & \multicolumn{2}{|c|}{ Patients $(\mathrm{n}=198)$} & \multirow[t]{2}{*}{$p$-Value ${ }^{\mathrm{a}}$} \\
\hline & $\mathrm{n}$ & $\%$ & $\mathrm{n}$ & $\%$ & \\
\hline \multicolumn{6}{|l|}{ Age (years) } \\
\hline $25 \sim 40$ & 285 & $63.4 \%$ & 133 & $67.2 \%$ & \\
\hline$>40$ & 168 & $36.6 \%$ & 65 & $32.8 \%$ & 0.3286 \\
\hline \multicolumn{6}{|l|}{ Gender } \\
\hline Male & 190 & $41.9 \%$ & 83 & $41.9 \%$ & \\
\hline Female & 263 & $58.1 \%$ & 115 & $58.1 \%$ & 0.9956 \\
\hline \multicolumn{6}{|l|}{ Smoking habits } \\
\hline Yes & 48 & $10.6 \%$ & 37 & $18.7 \%$ & \\
\hline No & 405 & $89.4 \%$ & 161 & $81.3 \%$ & $0.0048 *$ \\
\hline
\end{tabular}

aBased on Chi-square test; $* p<0.05$, Statistically identified as significant.

Table II. Distribution of CHI3L1 -131C/G genotypes among asthma patients and controls.

\begin{tabular}{|c|c|c|c|c|c|c|}
\hline \multirow[t]{2}{*}{$-131 \mathrm{C} / \mathrm{G}$} & \multicolumn{2}{|c|}{ Controls } & \multicolumn{2}{|c|}{ Patients } & \multirow[t]{2}{*}{ OR $(95 \% \mathrm{CI})$} & \multirow[t]{2}{*}{$p$-Value ${ }^{\mathrm{a}}$} \\
\hline & $\mathrm{n}$ & $\%$ & $\mathrm{n}$ & $\%$ & & \\
\hline \multicolumn{7}{|l|}{ Genotype } \\
\hline $\mathrm{CC}$ & 331 & $73.1 \%$ & 118 & $59.6 \%$ & 1.00 (reference) & \\
\hline CG & 108 & $23.8 \%$ & 65 & $32.8 \%$ & $1.69(1.16-2.45)$ & $0.0056^{*}$ \\
\hline GG & 14 & $3.1 \%$ & 15 & $7.6 \%$ & $3.00(1.41-6.41)$ & $0.0030^{*}$ \\
\hline$P_{\text {trend }}$ & & & & & & $0.0009^{*}$ \\
\hline \multicolumn{7}{|c|}{ Carrier analysis } \\
\hline $\mathrm{CC}+\mathrm{CG}$ & 439 & $96.9 \%$ & 183 & $92.4 \%$ & 1.00 (reference) & \\
\hline GG & 14 & $3.1 \%$ & 15 & $7.6 \%$ & $2.57(1.22-5.43)$ & $0.0107 *$ \\
\hline $\mathrm{CC}$ & 331 & $73.1 \%$ & 118 & $59.6 \%$ & 1.00 (reference) & \\
\hline $\mathrm{CG}+\mathrm{GG}$ & 122 & $26.9 \%$ & 80 & $40.4 \%$ & $1.84(1.29-2.61)$ & $0.0006 *$ \\
\hline
\end{tabular}

aBased on chi-square test without Yates' correction; ${ }^{*} p<0.05$, Statistically identified as significant; OR: odds ratio; CI: confidence interval.

under the supervision of the Human Research Committees of China Medical University hospital (CMUH106-REC1-004). Five ml of venous blood sample from each participant were collected and used for DNA extraction and further genotyping.

CHI3L1 genotyping methodologies. The genomic DNA was extracted from each participant's peripheral blood leukocytes within $24 \mathrm{~h}$, carefully quantitated, diluted and stored at $-80^{\circ} \mathrm{C}$ until further processed (13-16). In the current study, the genotypes at CHI3L1 $-131 \mathrm{C} / \mathrm{G}$ (rs4950928) and -247G/A (rs1262491437) were determined for all the investigated subjects via polymerase chain reactionrestriction fragment length polymorphism (PCR-RFLP) using the BioRad Mycycler machine (BioRad, Hercules, CA, USA). All PCR reactions were performed in a total volume of $25 \mu \mathrm{l}$ containing $5 \mu \mathrm{l}$ $10 \times$ Buffer, $2 \mu \mathrm{l}$ template DNA, $1 \mu \mathrm{l}(20 \mu \mathrm{M})$ upstream primer, $1 \mu \mathrm{l}(20$ $\mu \mathrm{M})$ downstream primer, $0.5 \mu \mathrm{T}$ Taq DNA polymerase, $2 \mu \mathrm{dNTP}$, and $13.5 \mu \mathrm{l}$ deionized sterile water. PCR procedures were as follows: $95^{\circ} \mathrm{C}$ initial denaturation for $5 \mathrm{~min}$; followed by 40 cycles of denaturing at $95^{\circ} \mathrm{C}$ for $30 \mathrm{~s}$, annealing at $55^{\circ} \mathrm{C}$ for $30 \mathrm{~s}$ and extension for $30 \mathrm{~s}$ at $72^{\circ} \mathrm{C}$; final extension at $72^{\circ} \mathrm{C}$ for $10 \mathrm{~min}$. Then the genotypes were identified after the $3 \%$ DNA agarose gel electrophoresis.
Statistical analysis. The Student's $t$-test was applied for the comparison of age index between the asthma and the control groups. Pearson's Chi-square or Fisher's exact test (as any number was less than 5) was applied to compare the distributions of the numbers among the subgroups. The Hardy-Weinberg equilibriums were checked by chi-square goodness-of-fit test $(p>0.05)$ using gene frequencies of the healthy individuals in the control group. The associations between $C H I 3 L 1$ genotypes and asthma risk were estimated by calculating the odds ratios (ORs) and their 95\% confidence intervals (95\% CIs) from logistic regression analysis. Statistically, any difference between any two groups compared with $p<0.05$ was considered as significant.

\section{Results}

Subject demographics. Baseline characteristics of the 198 cases and 453 non-asthmatic controls are presented in Table I. The case group consisted of 83 males and 115 females while 190 males and 263 females were in the control group. Since we matched all the controls and cases by age and gender criteria, 
Table III. Distribution of CHI3L1 -131C/G alleles among asthma patients and controls.

\begin{tabular}{lcccccc}
\hline & Controls & $\%$ & Patients & $\%$ & OR (95\%CI) & $p$-Value \\
\hline$-131 \mathrm{C} / \mathrm{G}$ & & & & & & \\
Allele C & 770 & $85.0 \%$ & 301 & $76.0 \%$ & 1.00 (reference) \\
Allele G & 136 & $15.0 \%$ & 95 & $24.0 \%$ & $1.79(1.33-2.40)$ & $<0.0001^{*}$ \\
\hline
\end{tabular}

aBased on chi-square test; ${ }^{*} p<0.05$, Statistically identified as significant; OR: odds ratio; CI: confidence interval.

Table IV. Distribution of CHI3L1 -247G/A genotypes among asthma patients and controls.

\begin{tabular}{|c|c|c|c|c|c|c|}
\hline \multirow[t]{2}{*}{$-247 \mathrm{G} / \mathrm{A}$} & \multicolumn{2}{|c|}{ Controls } & \multicolumn{2}{|c|}{ Patients } & \multirow[t]{2}{*}{ OR $(95 \% \mathrm{CI})$} & \multirow[t]{2}{*}{$p$-Value ${ }^{\mathrm{a}}$} \\
\hline & $\mathrm{n}$ & $\%$ & $\mathrm{n}$ & $\%$ & & \\
\hline \multicolumn{7}{|l|}{ Genotype } \\
\hline GG & 231 & $51.0 \%$ & 99 & $50.0 \%$ & 1.00 (reference) & \\
\hline AG & 186 & $41.1 \%$ & 79 & $39.9 \%$ & $0.99(0.70-1.41)$ & 0.9602 \\
\hline AA & 36 & $7.9 \%$ & 20 & $10.1 \%$ & $1.30(0.71-2.35)$ & 0.3919 \\
\hline \multirow{2}{*}{\multicolumn{7}{|c|}{$\begin{array}{l}\text { trend } \\
\text { Carrier analysis }\end{array}$}} \\
\hline & & & & & & \\
\hline $\mathrm{GG}+\mathrm{AG}$ & 417 & $92.1 \%$ & 178 & $89.9 \%$ & 1.00 (reference) & \\
\hline AA & 36 & $7.9 \%$ & 20 & $10.1 \%$ & $1.30(0.71-2.35)$ & 0.3672 \\
\hline GG & 231 & $51.0 \%$ & 99 & $50.0 \%$ & 1.00 (reference) & \\
\hline $\mathrm{AG}+\mathrm{AA}$ & 222 & $49.0 \%$ & 99 & $50.0 \%$ & $1.04(0.75-1.45)$ & 0.8156 \\
\hline
\end{tabular}

'Based on chi-square test without Yates' correction; OR: odds ratio; CI: confidence interval.

Table V. Distribution of CHI3L1 -247G/A alleles among asthma patients and controls.

\begin{tabular}{lcccccc}
\hline & Controls & $\%$ & Patients & $\%$ & OR (95\%CI) & $p$-Value \\
\hline -247G/A & & & & & & \\
Allele G & 648 & $71.5 \%$ & 277 & $70.0 \%$ & 1.00 (reference) \\
Allele A & 258 & $28.5 \%$ & 119 & $30.0 \%$ & $1.08(0.83-1.40)$ & 0.5646 \\
\hline
\end{tabular}

aBased on chi-square test; OR: odds ratio; CI: confidence interval.

there was no difference between the case and control groups regarding age and gender ( $p=0.2972$ and 0.9956 , respectively). Noticeably, a higher number of smokers were in the asthma group than in the control group ( $p=0.0048$ ) (Table I).

Analysis of CHI3L1 promoter SNPs. All subjects were successfully genotyped and no deviation from HardyWeinberg equilibrium was observed in $C H I 3 L 1-131 \mathrm{C} / \mathrm{G}$ or 247G/A ( $p>0.05)$. The distributions of the CHI3L1 -131C/G genotypes among the 198 asthma cases and the 453 nonasthmatic controls are presented and compared in Table II. The results show that the genotype CHI 3 L1 $-131 \mathrm{C} / \mathrm{G}$ are differently distributed between the asthma patient and healthy control groups ( $p$ for trend=0.0009). In detail, the CHI3L1 -131C/G heterozygous variant CG and the homozygous variant GG were associated with elevated asthma risk, compared with the wild-type $\mathrm{CC}$ genotype $(\mathrm{OR}=1.69$ and $3.00,95 \% \mathrm{CI}=1.16-2.45$ and $1.41-6.41$, respectively). The dominant and recessive models also showed statistical significances $(\mathrm{OR}=2.57$ and 1.84, $95 \% \mathrm{CI}=1.22-5.43$ and $1.29-2.61$, respectively).

To confirm the novel findings in Table II, the allelic frequency distribution for $C H I 3 L 1-131 \mathrm{C} / \mathrm{G}$ was analyzed and the results are presented in Table III. The results confirmed that the variant $\mathrm{G}$ allele at $C H I 3 L 1-131 \mathrm{C} / \mathrm{G}$ was associated with a relatively increased risk of asthma compared to the wild-type $\mathrm{C}$ allele $(\mathrm{OR}=1.79,95 \% \mathrm{CI}=1.33$ 2.40). On the other hand, neither the AG nor AA genotype at $C H I 3 L 1-247 \mathrm{G} / \mathrm{A}$ were associated with asthma risk among the Taiwanese (Table IV). Also, analysis of allelic frequency distribution showed no significant difference regarding the polymorphism CHI3L1 -247G/A (Table V). 


\section{Discussion}

In the current study, the CHI3L1 genotypes were found to contribute to asthma risk in a representative population in Taiwan. It has been reported that people having the wild-type genotype $\mathrm{CC}$ at the promoter $\mathrm{CHI} 3 \mathrm{~L} 1-131 \mathrm{C} / \mathrm{G}$ polymorphic site, overexpressed the protein and had elevated serum YKL40 levels compared with CG or GG genotypes (8). However, $\mathrm{Li}$ and his colleagues have demonstrated that an association between CHI3L1 -131G and childhood asthma was found (17). While, Ober and his colleagues reported that $-131 \mathrm{C}$ was associated with childhood asthma in another study (8). Moreover, another group found no significant association between the genetic polymorphism in the CHI3L1 -131C/G and asthma risk $(18,19)$. There are genetic differences among populations and the etiology of childhood and adult asthma may differ from each other.

Accumulating evidence has indicated that CHI3L1 gene polymorphisms might contribute to the etiology of adult asthma. Kjaergaard and his colleagues have performed an excellent study, investigating the genotypes of 9000 individuals. They have identified 59 polymorphic sites in CHI3L1 gene, and fifteen of them were associated with the expression levels of plasma YKL-40 (20). We found that the CHI3L1 - 131C/G polymorphism, which is located in the promoter region of $C H I 3 L 1$ gene, was significantly associated to asthma risk. Several studies have investigated the contribution of this polymorphism to asthma risk, but the conclusions are controversial. For instance, Ober and his colleagues have identified that the $\mathrm{C}$ allele in CHI3L1 $131 \mathrm{C} / \mathrm{G}$ is the risk allele for asthma, whereas Rathcke and his colleagues have reported that the $\mathrm{G}$ allele was associated with elevated asthma risk in a Caucasian population $(8,21)$. Our data showed that the $G$ allele was associated with increased asthma risk in Taiwan population (Table II). Therefore, additional studies are necessary to reveal the role of $C H I 3 L 1-131 \mathrm{C} / \mathrm{G}$ for asthma. Tsai and his colleagues have examined the association of the CHI 3 LI with asthma. They examined ten tagSNPs (rs903358, rs7542294, rs946259, rs880633, rs12128727, rs1538372, rs10399805, rs10399931, rs6691378, and rs946261) and found rs1538372 and rs10399931 to be significantly associated with asthma risk in a Taiwan population (22).

Serum YKL-40 levels are not a specific diagnostic tool, since they are elevated in several diseases such as multiple sclerosis, rheumatoid arthritis, osteoarthritis, infectious diseases, cardiovascular disease, and cancer. YKL-40 may not serve as a good diagnostic biomarker for asthma, but it has been reported to be associated with poor prognosis (6) and overall mortality risk (23). The correlation of serum YKL-40 levels and CHI3L1 genotypes has yet to be validated.

In conclusion, the results may provide novel evidence showing that the variant $\mathrm{G}$ allele of $C H I 3 L 1-131 \mathrm{C} / \mathrm{G}$ may play an important role in determining the susceptibility to asthma among Taiwanese.

\section{Funding}

This study was supported mainly by Taichung Armed Forces General Hospital (TCAFGH-D-109012) to Dr. Chen and partially by the China Medical University Hospital (DMR-110-181) to Dr. Tsai.

\section{Conflicts of Interest}

All the Authors have declared no conflicts of interest in relation to this study.

\section{Authors' Contributions}

Research design: Chen CL and Wang SC; patient and questionnaire summaries: Chen CL, Shen TC and Hsia TC; experimental work: Chang WS and Tsai CW; statistical analysis: Wang SC, Lin C and Chang WS; article writing: Tsai $\mathrm{CW}$ and $\mathrm{Bau}$ DT; review and revision: Tsai $\mathrm{CW}$ and Bau DT.

\section{Acknowledgements}

The Authors thank TissueBank of China Medical University Hospital for their excellent technical assistance in collection the information, data, and samples. Expert genotyping assistance was kindly provided by Yu-Chen Hsiau, Yu-Ting Chin and Tai-Lin Huang.

\section{References}

1 Madore AM, Perron S, Turmel V, Laviolette M, Bissonnette EY and Laprise C: Alveolar macrophages in allergic asthma: an expression signature characterized by heat shock protein pathways. Hum Immunol 71(2): 144-150, 2010. PMID: 19913588. DOI: 10.1016/j.humimm.2009.11.005

2 Mattiuzzi C and Lippi G: Worldwide asthma epidemiology: insights from the Global Health Data Exchange database. Int Forum Allergy Rhinol 10(1): 75-80, 2020. PMID: 31645084. DOI: $10.1002 /$ alr.22464

3 Masoli M, Fabian D, Holt S, Beasley R and Global Initiative for Asthma P: The global burden of asthma: executive summary of the GINA Dissemination Committee report. Allergy 59(5): 469478, 2004. PMID: 15080825. DOI: 10.1111/j.1398-9995.2004. 00526.x

4 Maddox L and Schwartz DA: The pathophysiology of asthma. Annu Rev Med 53: 477-498, 2002. PMID: 11818486. DOI: 10.1146/annurev.med.53.082901.103921

5 Wills-Karp M and Ewart SL: Time to draw breath: asthmasusceptibility genes are identified. Nat Rev Genet 5(5): 376-387, 2004. PMID: 15143320 . DOI: $10.1038 / \operatorname{nrg} 1326$

6 Johansen JS: Studies on serum YKL-40 as a biomarker in diseases with inflammation, tissue remodelling, fibroses and cancer. Dan Med Bull 53(2): 172-209, 2006. PMID: 17087877.

7 Hakala BE, White C and Recklies AD: Human cartilage gp-39, a major secretory product of articular chondrocytes and synovial cells, is a mammalian member of a chitinase protein family. $\mathrm{J}$ Biol Chem 268(34): 25803-25810, 1993. PMID: 8245017. 
8 Ober C, Tan Z, Sun Y, Possick JD, Pan L, Nicolae R, Radford S, Parry RR, Heinzmann A, Deichmann KA, Lester LA, Gern JE, Lemanske RF, Jr., Nicolae DL, Elias JA and Chupp GL: Effect of variation in CHI3L1 on serum YKL-40 level, risk of asthma, and lung function. N Engl J Med 358(16): 1682-1691, 2008. PMID: 18403759. DOI: 10.1056/NEJMoa0708801

9 Boot RG, van Achterberg TA, van Aken BE, Renkema GH, Jacobs MJ, Aerts JM and de Vries CJ: Strong induction of members of the chitinase family of proteins in atherosclerosis: chitotriosidase and human cartilage gp-39 expressed in lesion macrophages. Arterioscler Thromb Vasc Biol 19(3): 687-694, 1999. PMID: 10073974. DOI: 10.1161/01 atv.19.3.687

10 Shackelton LM, Mann DM and Millis AJ: Identification of a 38$\mathrm{kDa}$ heparin-binding glycoprotein (gp38k) in differentiating vascular smooth muscle cells as a member of a group of proteins associated with tissue remodeling. J Biol Chem 270(22): 1307613083, 1995. PMID: 7768902. DOI: 10.1074/jbc.270.22.13076

11 Volck B, Price PA, Johansen JS, Sorensen O, Benfield TL, Nielsen HJ, Calafat J and Borregaard N: YKL-40, a mammalian member of the chitinase family, is a matrix protein of specific granules in human neutrophils. Proc Assoc Am Physicians 110(4): 351-360, 1998. PMID: 9686683.

12 Lee CG, Hartl D, Lee GR, Koller B, Matsuura H, Da Silva CA, Sohn MH, Cohn L, Homer RJ, Kozhich AA, Humbles A, Kearley J, Coyle A, Chupp G, Reed J, Flavell RA and Elias JA: Role of breast regression protein 39 (BRP-39)/chitinase 3-like1 in Th2 and IL-13-induced tissue responses and apoptosis. J Exp Med 206(5): 1149-1166, 2009. PMID: 19414556. DOI: 10.1084/jem.20081271

13 Tsai CL, Tsai CW, Chang WS, Su CH, Liu LC, Wang HC, Lee HT, Yen CM, Chen JC, Wang YC, Chen CH and Bau DT: Interleukin-13 promoter genotypes and Taiwanese breast cancer susceptibility. Anticancer Res 40(12): 6743-6749, 2020. PMID: 33288567. DOI: $10.21873 /$ anticanres. 14697

14 Shih LC, Tsai CW, Chang WS, Shen TC, Wang YC, Yang JS, Lin ML, Wang ZH and Bau DT: Association of caspase-8 genotypes with the risk for nasopharyngeal carcinoma in Taiwan. Anticancer Res 40(10): 5503-5508, 2020. PMID: 32988873. DOI: 10.21873 /anticanres.14562

15 Chen LH, Chiu KL, Hsia TC, Lee YH, Shen TC, Li CH, Shen YC, Chang WS, Tsai CW and Bau DT: Significant association of MMP2 promoter genotypes to asthma susceptibility in Taiwan. In Vivo 34(6): 3181-3186, 2020. PMID: 33144422. DOI: 10.21873 /invivo.12153
16 Wu MF, Wang YC, Shen TC, Chang WS, Li HT, Liao CH, Gong CL, Wang ZH, Tsai CW, Hsia TC and Bau DT: Significant association of interleukin-16 genetic variations to Taiwanese lung cancer. In Vivo 34(3): 1117-1123, 2020. PMID: 32354900. DOI: 10.21873 /invivo. 11883

17 Li JM, Zhang HF, Shen XL, Xie H, Wu XD, Shen T and Wang Y: Association between CHI3L1 SNPs and susceptibility to childhood asthma. Zhongguo Dang Dai Er Ke Za Zhi 17(2): 144-148, 2015. PMID: 25760838.

18 James AJ, Reinius LE, Verhoek M, Gomes A, Kupczyk M, Hammar U, Ono J, Ohta S, Izuhara K, Bel E, Kere J, Soderhall C, Dahlen B, Boot RG, Dahlen SE and Consortium B: Increased YKL-40 and chitotriosidase in asthma and chronic obstructive pulmonary disease. Am J Respir Crit Care Med 193(2): 131-142, 2016. PMID: 26372680. DOI: 10.1164/rccm.201504-0760OC

19 Ramphul K, Hua L, Bao YX, Li JY, Liu QH, Ji RX and Fang DZ: Identification of IL13 C1923T as a single nucleotide polymorphism for asthma in children from Mauritius. Pediatr Allergy Immunol Pulmonol 28(2): 92-95, 2015. PMID: 26155367. DOI: 10.1089/ped.2014.0464

20 Kjaergaard AD, Johansen JS, Nordestgaard BG and Bojesen SE: Genetic variants in CHI3L1 influencing YKL-40 levels: resequencing 900 individuals and genotyping 9000 individuals from the general population. J Med Genet 50(12): 831-837, 2013. PMID: 24062521. DOI: 10.1136/jmedgenet-2013-101908

21 Rathcke CN, Holmkvist J, Husmoen LL, Hansen T, Pedersen O, Vestergaard $\mathrm{H}$ and Linneberg A: Association of polymorphisms of the CHI3L1 gene with asthma and atopy: a populations-based study of 6514 Danish adults. PLoS One 4(7): e6106, 2009. PMID: 19568425. DOI: 10.1371/journal.pone.0006106

22 Tsai Y, Ko Y, Huang M, Lin M, Wu C, Wang C, Chen Y, Li J, Tseng Y and Wang T: CHI3L1 polymorphisms associate with asthma in a Taiwanese population. BMC Med Genet 15: 86, 2014. PMID: 25056157. DOI: 10.1186/1471-2350-15-86

23 Mygind ND, Iversen K, Kober L, Goetze JP, Nielsen H, Boesgaard S, Bay M, Johansen JS, Nielsen OW, Kirk V and Kastrup J: The inflammatory biomarker YKL-40 at admission is a strong predictor of overall mortality. J Intern Med 273(2): 205216, 2013. PMID: 23140269. DOI: 10.1111/joim.12006

Received January 9, 2021

Revised January 24, 2021

Accepted January 25, 2021 